\title{
ANALYSIS OF THE ANXIETY ABOUT COVID-19 PANDEMIC WITH BREAST MILK PRODUCTION IN BREASTFEEDING MOTHERS
}

\author{
Ni Made Ari Febriyanti", A.A Santi Dewi \\ "Midwifery Department, Kartini Health Polytechnic of Bali, Jl. Piranha No.2 Pegok, Sesetan, Denpasar \\ Selatan, Bali 80223 telp. (0361) 720471, Indonesia \\ Corresponding author: \\ E-mail:arifebri89@gmail.com
}

\begin{abstract}
Background: The postpartum period is a process that begins after the birth of the baby until the organs return to the way they were before pregnancy. There are complex physical and psychological changes. One of the psychological disorders that often occurs after childbirth is anxiety. This anxiety disorder will also indirectly affect the release of breast milk so that it interferes with the process of breastfeeding. The purpose of this study was to determine the relationship between anxiety during the COVID-19 pandemic and the production of breast milk in breastfeeding mothers.

Methods: The design of this study was cross-sectional analytic. This study was carried out at East Denpasar Health Center I with a sample size of 30 respondents who met the inclusion criteria. The sampling technique of this research is purposive sampling. The independent variable in this study is anxiety and the dependent variable is the breast milk production. Data were collected using the Zung Self Rating Anxiety Scale (ZSAS) questionnaire and data analysis was carried out in stages including univariate and bivariate (Rank Spearman).

Result: The results showed that most (60\%) of respondents did not experience anxiety and most $(60 \%)$ of respondents released breast milk quickly. Bivariate results show that there is a significant relationship between anxiety during the COVID-19 pandemic and the production of breast milk in breastfeeding mothers $(p=0.0001)$ with a correlation coefficient of 0.738 .

Conclusion: There is a relationship between anxiety and breastmilk production. The lower mother's anxiety, the better the production of her milk.
\end{abstract}

Keywords: Anxiety, breastfeeding mothers, breastmilk production 


\section{INTRODUCTION}

The postpartum period is a stage that begins after the birth of the baby until the restoration of organs as before birth, the length of the postpartum period is about 68 weeks $^{[1]}$. At this time, mothers will also experience physiological, psychological and social adaptations. One of the psychological disorders of mothers that often occurs after giving birth is anxiety.

Anxiety is a feeling of worry, nervousness, or restlessness with uncertain results and can lead to depression ${ }^{[2]}$. Based on data on the prevalence of anxiety levels of primiparous postpartum mothers in Portugal (18.2\%), Bangladesh (29\%), Hong Kong (54\%), and Pakistan $(70 \%)^{[3]}$. Anxiety that occurs in postpartum mothers caused by the changes in the mother's role.

During the COVID-19 pandemic, there were many restrictions on almost all routine health services, both in terms of access and quality, including restrictions on maternal and neonatal health services. These conditions can cause psychological problems for postpartum mothers. The anxiety felt by postpartum mothers is the fear of being infected with COVID-19, the anxiety of not being able to breastfeed, the anxiety of bleeding, other anxiety is the absence of friends or family who visit and care for their baby ${ }^{[4]}$.

This anxiety disorder will also indirectly affect the release of breast milk so that it interferes with the process of breastfeeding the mother to the baby. Based on the results of research on the factors that affect breastfeeding, where the production of breastfeeding is influenced by peace of $\operatorname{mind}^{[5]}$. If the mother experiences stress, lack of rest, discomfort, anxiety, disturbed thoughts, and tension, it will indirectly affect milk production ${ }^{[6]}$.

Based on the above background, the researchers are interested in conducting a research of the relationship between anxiety during the COVID-19 pandemic and the production of breast milk in breastfeeding mothers.

\section{METHODS}

This study is an analytical study with a cross-sectional research design to determine the relationship between anxiety during the COVID-19 pandemic and the production of breast milk in breastfeeding mothers. The independent variable in this study is anxiety during the COVID-19 pandemic, while the dependent variable is the production of breast milk. The sampling technique used was purposive sampling. The study was conducted at East Denpasar Health Center I, where the number of samples was 30 postpartum mothers with inclusion criteria for postpartum mothers on 0-7 days, mothers who were breastfeeding and willing to be respondents. Data was collected by administering a questionnaire, where previously the postpartum mother was selected according to the inclusion criteria, after that an informed consent sheet and a questionnaire sheet were given.

The measuring instrument in this study is a standardized questionnaire, the Zung Self Rating Anxiety Scale (ZSAS) with normal criteria if the score is 20-44, mild if the score is $45-59$, moderate if the score is $60-74$ and severe if the score is 75-80. Data analysis was carried out computerized using the SPSS program with Spearman Rank statistical test.

\section{RESULTS}

\section{Univariate Analysis}

Univariate analysis was used to determine the distribution of research variables which include characteristics, anxiety and breast milk production. 
Table 1. Characteristics of Respondents $(\mathbf{n}=\mathbf{3 0})$

\begin{tabular}{lcc}
\hline $\begin{array}{l}\text { Characteristics of } \\
\text { Respondents }\end{array}$ & (f) & $\%$ \\
\hline $\begin{array}{l}\text { Age } \\
\text { <20 years old }\end{array}$ & 1 & 3,3 \\
$\begin{array}{l}\text { 20-35 years old } \\
\text { Education }\end{array}$ & 29 & 96,7 \\
$\begin{array}{l}\text { Low (elementary and } \\
\text { junior highschool) }\end{array}$ & 12 & 40,0 \\
$\begin{array}{l}\text { High (senior high } \\
\text { school }\end{array}$ & 18 & 60,0 \\
$\begin{array}{l}\text { university) and } \\
\begin{array}{l}\text { Parity } \\
\text { Primipara }\end{array}\end{array}$ & & \\
$\begin{array}{l}\text { Multipara } \\
\text { Employment }\end{array}$ & 7 & 23,3 \\
Unemployed & 22 & 76,7 \\
Employed & 8 & 73,3 \\
\hline
\end{tabular}

Table 1 shows the majority of respondents aged 20-35 years old, namely 29 respondents $(96.7 \%), 18$ respondents (60.0\%) had higher education (SMA-PT), 23 respondents $(76.7 \%)$ were multiparous. and as many as 22 respondents $(73.3 \%)$ do not work.

Table 2. Anxiety during the COVID-19 Pandemic ( $\mathbf{n = 3 0})$

\begin{tabular}{lcc}
\hline \multicolumn{1}{c}{ Anxiety } & Frequency & $\boldsymbol{\%}$ \\
\hline Normal & 18 & 60,0 \\
Mild & 8 & 26,7 \\
Currently & 4 & 13,3 \\
anxious & & \\
\hline
\end{tabular}

Table 2 shows that most of the respondents did not experience anxiety, as many as 18 respondents (60.0\%) almost half of them, which are eight $(26.7 \%)$ respondents experienced mild anxiety and four $(13.3 \%)$ respondents experienced moderate anxiety.

Table 3. Breast Milk Production

\begin{tabular}{lcc}
$\begin{array}{c}\text { Breast milk } \\
\text { production }\end{array}$ & Frequency & $\%$ \\
\hline Fast & 18 & 60,0 \\
Slow & 12 & 40,0 \\
\hline
\end{tabular}

Table 3 shows that most of the $18(60 \%)$ respondents release breast milk quickly, namely 3 days, and 12 (40\%) respondents expressed breast milk slowly, namely $>3$ days.

\section{Bivariate Analysis}

Bivariate analysis of research variables using the Spearman Rank statistical test to explain the relationship between anxiety during the COVID-19 pandemic and the production of breast milk in breastfeeding mothers.

Table 4. The Relationship Between Anxiety and Breastmilk Production $(\mathbf{n}=30)$

\begin{tabular}{|c|c|c|c|c|}
\hline \multirow{2}{*}{ Anxiety } & \multicolumn{2}{|c|}{$\begin{array}{l}\text { Breastmilk } \\
\text { Production }\end{array}$} & \multirow{2}{*}{$\begin{array}{c}p- \\
\text { value }\end{array}$} & \multirow{2}{*}{$\begin{array}{c}\text { Corre } \\
\text { ation } \\
\text { coeffic } \\
\text { ient } \\
\end{array}$} \\
\hline & $\begin{array}{l}\text { Fast } \\
\text { n (\%) }\end{array}$ & $\begin{array}{c}\text { Slow } \\
\text { n (\%) }\end{array}$ & & \\
\hline Normal & $16(88,9)$ & $2(11,1)$ & 0,0001 & 0,738 \\
\hline Mild & $2(25,0)$ & $6(75,0)$ & & \\
\hline $\begin{array}{l}\text { Currently } \\
\text { anxious }\end{array}$ & $0(0)$ & $4(100)$ & & \\
\hline
\end{tabular}

Table 4 shows that there is a relationship between anxiety and the production of breast milk with a $\mathrm{p}$ value $=0.0001$ and a correlation coefficient of 0.738 .

DISCUSSION
nervousness or restlessness about something with uncertain results and can lead to depression ${ }^{[2]}$. The symptoms experienced by mothers are dominated by psychological factors, but can also be caused by physical factors. A person will experience an anxiety disorder when the person concerned is unable to cope with psychosocial stressors ${ }^{[7]}$.

Based on the results of the study, most of the mothers $(60.0 \%)$ did not experience anxiety, almost half of the mothers (26.7\%) experienced mild anxiety, and a $13.3 \%$ experienced moderate anxiety. In this study, most of the respondents did not experience 
anxiety, because most of the respondents had a high level of education. A person's level of education has a direct impact on anxiety. A person's level of education is related to his knowledge of a specific problem which is also high. So that the higher a person's level of knowledge, the lower the level of anxiety ${ }^{[8]}$.

Anxiety is not only emotionally painful but because there is an error in knowledge, the more knowledge one knows, the easier it will be to overcome anxiety. Every woman who will enter her new role as a mother must have adequate knowledge about the physiology of breastfeeding so that she can undergo a calmer postpartum period so that the woman does not experience anxiety ${ }^{[8]}$.

In addition, in this study, most of the respondents were multiparous, where previous childbirth experiences also contributed to influencing a mother's level of anxiety in facing her new role which would have an impact on her milk production. For mothers who have never had experience in the birthing process and how to give breast milk before, they will experience a lot of severe anxiety, because the mother is afraid of her own thoughts and images about how to breastfeed her baby, at least spending breast milk, how to care for a baby and so on. On the other hand, mothers who have given birth and are experienced in breastfeeding will understand more and will be calmer ${ }^{[9]}$.

Based on the results of the study, it showed that the flow of breast milk in breastfeeding mothers mostly (60\%) expressed breast milk quickly, namely 3 days and almost half (40\%) expressed breast milk slowly, namely > 3 days. Breast milk production is influenced by several factors such as breastfeeding behavior, mother's psychology, mother's physiology, mother's nutritional status, breast care and breastfeeding frequency ${ }^{[9]}$. In this study, most of the mothers were multiparous. Mothers who gave birth more than once were able to produce more milk than those who gave birth for the first time ${ }^{[9]}$. A person who has given birth for the first time usually has less knowledge and experience in terms of breastfeeding, while a mother who has given birth more than once certainly has experience in breastfeeding so that lactation management will be carried out properly. In addition, psychological readiness between primipara and multipara mothers is very different. A primipara is easier to feel anxious and his psychological condition is unstable so that it will affect the release of hormones that play a role in milk production ${ }^{[9]}$. This is what causes the increase in breast milk production for multiparous mothers more quickly than primiparas.

The results of this study showed that almost all (88.9\%) respondents who were not anxious felt that their breast milk was released quickly. Most (75.0\%) respondents who had mild anxiety felt that the flow of breast milk was slow and all $(100 \%)$ respondents who had moderate anxiety felt that their milk ejection was slow. This shows that a good mother's psychological condition can have a good impact on the flow of breast milk.

Based on the results of bivariate analysis, it is known that the significance value or sig (2-tailed) is 0.0001 so that the $\mathrm{p}$ value $<0.05$, it is concluded that there is a significant relationship between the level of maternal anxiety and the flow of breast milk with a correlation coefficient of 0.738 which means there is a relationship with a unidirectional nature where the lower the mother's anxiety, the faster the release of her milk.

Anxiety is an emotional response to subjective individual judgments where the situation is influenced by the subconscious and the cause is unknown. Prolonged feelings of anxiety can make postpartum mothers unable to concentrate properly and a loss of self-confidence. Symptoms of postpartum anxiety can be seen from irritability, difficulty in socializing and communicating, stress, sleep deprivation, palpitations or a fast 
heart rate, frequent urination, abdominal pain or diarrhea, sweaty and shaking hands, tingling feet and hands, muscle spasms, frequent dizziness, and fainting ${ }^{[7]}$. At the beginning of postpartum, postpartum mothers will feel a lot of feelings of anxiety, these feelings will cause blocking of the let-down reflect mechanism. Stress will trigger the release of the hormone epinephrine or adrenaline which causes constriction of the blood vessels in the alveolus. Then, the oxytocin which should be able to reach its target, which is the myopic cells around the alveolus to contract and push the milk that has been made, into the lactiferous ducts is not carried out, so it can inhibit production of breast milk products (colostrum, transitional breast milk, mature breast milk ${ }^{[10]}$. On the other hand, if the mother's psychology is calm, the letdown reflect mechanism will not be altered either.

These results are in line with Rehkliana's research which states that there is a relationship between the anxiety of the COVID-19 pandemic and the production of postpartum mother's milk. ( $\mathrm{p}$ value : $0.000<\alpha: 0.05)^{[11]}$. This study is also in accordance with research conducted by Arfiah, showing that there is a relationship between anxiety levels and breastfeeding during the puerperium with breastfeeding $\mathrm{p}$ value $=0,002<0,05^{[12]}$. Another study, by Mardjun, showed that there was a relationship between anxiety and the production of breast milk in postpartum mothers with $\mathrm{p}$ value $0,001<$ $0,05^{[13]}$. Anxiety that occurs in postpartum mothers occurs because of changes in the mother's role. Lack of knowledge of mothers in infant care can cause psychological disorders of anxiety. If the mother experiences stress, lack of rest, discomfort, anxiety, disturbed thoughts, and tension, it will affect milk production $^{[6]}$. Anxious mothers will express less milk than mothers who are not anxious.

\section{CONCLUSION}

Based on the results of the study, there was a significant relationship between the level of maternal anxiety and the flow of breast milk.

This study can be used as a reference for health workers in socializing the effects of anxiety on the breastfeeding process. The limitations in this study are the number of samples used was small and it is difficult to find samples during the COVID-19 pandemic, so the results of the study cannot be generalized to the wider population for the entire province of Bali. Suggestions given for further research are expected to use more samples and be developed by using other research variables.

\section{ACKNOWLEDGEMENTS}

We would like to thank to the Kartini Bali Health Polytechnic, East Denpasar Health Center I, research respondents, and all of the people who have helped in this research.

\section{REFERENCES}

1. Nurjanah, S.N Maemunah, A.S Badriah D. Asuhan Kebidanan postpartum. Bandung: Refika Aditama; 2013.

2. Kajdy A, Feduniw S, Ajdacka U, Modzelewski J, Baranowska B, Sys D, et al. Risk Factors For Anxiety And Depression Among Pregnant Women During The COVID-19 Pandemic: A Web-Based CrossSectional Survey. Medicine (Baltimore) [Internet] 2020 [cited 2022 Jan 7];99(30):e21279. Available from: /pmc/articles/PMC7387043/

3. Agustin IMS. Kecemasan Pada Ibu Post Partum Primipara Dengan Gangguan Proses Laktasi. J Ilmu Keperawatan Jiwa [Internet] 2018 [cited 2022 Jan 7];1(2):99-104. 
Available

from:

https://www.journal.ppnijateng.org/ index.php/jikj/article/view/133

4. Bender WR, Srinivas S, Coutifaris P, Acker A, Hirshberg A. The Psychological Experience of Obstetric Patients and Health Care Workers after Implementation of Universal SARS-cov-2 Testing. Am J Perinatol [Internet] 2020 [cited 2022 Jan 7];37(12):1271-9. Available from: https://pubmed.ncbi.nlm.nih.gov/32 757185/

5. Dewi ADC. Faktor-Faktor Yang Mempengaruhi Kelancaran Produksi ASI. J 'Aisyiyah Med [Internet] 2019 [cited 2022 Jan 7];4(0). Available from: https://jurnal.stikes-aisyiyahpalembang.ac.id/index.php/JAM/art icle/view/230

6. Riksani R. Keajaiban ASI (Air Susu Ibu). Jakarta: Dunia Sehat; 2012.

7. Hawari D. Menejemen Stres, Cemas dan Depresi. Jakarta: FKUI; 2016.

8. Yainanik Y, Nisa Rachmah NA. Usia Tingkat Pendidikan Dan Pengetahuan Antenatal Care Ibu Primigravida Dalam Kecemasan Menghadapi Persalinan. 2017;

9. Kodrat L. Dasyatnya ASI dan Laktasi (Untuk Kecerdasan Buah Hati). Yogyakarta: Media Baca; 2010.

10. Andina V s. Asuhan Kebidanan Nifas dan Menyusui, Teori Dalam Praktik Kebidanan Profesional. Yogyakarta: Pustaka Baru Press; 2018.

11. Rehkliana EL. Hubungan
Kecemasan Covid-19 Dengan Pengeluaran Asi Ibu Post Partum Di Rsia Khalishah. J Keperawatan BSI [Internet] 2020 [cited 2022 Jan 4];8(2):293-9. Available from: http://ejurnal.ars.ac.id/index.php/ke perawatan/article/view/606

12. Arfiah A. Pengaruh Tingkat Kecemasan pada Ibu Postpartum Primipara Remaja terhadap Kemampuan Pemenuhan Kebutuhan Bayi Baru Lahir di RSU Anuntapura Palu. J Ners Widya Nusant Palu (Ners J Widya Nusant Palu) [Internet] 2019 [cited 2022 Jan 12];2(1). Available from: https://ejournal.stikeswnpalu.ac.id/i ndex.php/JNWNP/article/view/7/1

13. Mardjun Z, Korompis G, Rompas S, Studi P, Keperawatan I, Kedokteran F. Hubungan Kecemasan Dengan Kelancaran Pengeluaran Asi Pada Ibu Post Partum Selama Dirawat Di Rumah Sakit Ibu Dan Anak Kasih Ibu Manado. J KEPERAWATAN [Internet] 2019 [cited 2022 Jan 12];7(1):1. Available from: https://ejournal.unsrat.ac.id/index.p $\mathrm{hp} / \mathrm{jkp} /$ article/view/22901 